\title{
Okul Öncesi Çocukların Yemek Yeme Davranışları ve Etkileyen Faktörlerin Belirlenmesi
}

\author{
Determination the Eating Behaviors and Affecting Factors of Preschool Children \\ Büşra Sema ALTUNSUYU ${ }^{1}$, Zehra ÇALIȘKAN² ${ }^{2}$ Semra KOCAÖZ
}

\begin{abstract}
ÖZ
$\mathrm{Bu}$ çalı̧̧ma, okul öncesi çocukların yemek yeme davranışları ve etkileyen faktörlerin belirlenmesi amacıyla tanımlayıcı olarak yapılmıştır. Araştırmanın örneklemini, Ortadoğu Anadolu bölgesindeki bir il merkezinde, sosyoekonomik düzeylerine göre tabakalandırılan 9 okulun 500 anasınıfı öğrencisi ve onların ebeveynleri oluşturmuştur. Veriler, EbeveynÇocuk Kişisel Veri Toplama Formu, Çocuklarda Yeme Davranışı Anketi (ÇYDA) ve antropometrik ölçümlerle toplanmıștır. Verilerin değerlendirilmesi bilgisayar ortamında tanımlayıc istatistikler, ki-kare independent t, kappa ve Anova (Post-hoc: Tukey) testleri kullanılarak yapılmıştır. Araștırmaya katılan okul öncesi çocukların, Beden Kütle İndeksi (BKİ)' ne göre $\% 21,4$ 'ünün zayıf, \%4,4'ünün fazla kilolu ve $\% 9,0$ 'unun obez olduğu, zayıflığın kızlarda $(\% 23,8)$, fazla kilolu ve obezitenin $(\% 14,3)$ erkeklerde fazla görüldüğü saptanmıştır ( $>00,05)$. Fazla kilolu ve obez çocukların, anne ve babalarının da fazla kilolu ve obez olduğu bulunmuştur $(\mathrm{p}<0,001)$. BKI' ye göre obez olan çocuklar $(\mathrm{n}=45)$, anneleri tarafindan normal $(\% 66,7)$ ve zayıf $(\% 2,2)$ olarak değerlendirilmiş, çocuğun BKI' si ile annenin çocuğun kilosunu değerlendirmesi arasında zayıf düzeyde $(\kappa=0,278 ; \quad p<0,001)$ uyum olduğu saptanmıştır. Çocukların yeme davranışlarını; çocuğun doğum kilosu, öğün sayısı ve öğün atlama durumu, fast-food tüketimi, ebeveyn yaklaşımları ve reklamların etkilediği tespit edilmiştir $(\mathrm{p}<0,05)$. Okul öncesi çocukların büyümelerinin izlenmesi, normalden sapmaların erken dönemde tespit edilmesi ve önlem alınması için hemşireler tarafından düzenli aralıklarla okullarda BKİ izlemlerinin yapılması, ebeveynleri fazla kilolu ve obez olan çocukların daha sık aralıklarla takip edilmesi önerilmektedir.
\end{abstract}

Anahtar Kelimeler: Çocuklarda yeme davranışı, Hemşirelik, Okul öncesi çocuk.

\begin{abstract}
This study was conducted as a descriptive study to determine the eating behaviours and affecting factors of preschool children. Sample of the study was composed of 500 kindergarten students of 9 schools which were stratified by socioeconomic levels in a city center in the Middle East Anatolia region and their parents. Data were collected with Parent and Child Personal Data Collection Form, Child Eating Behaviour Questionnaire (CEBQ) and anthropometric measurements. Data were analyzed with descriptive statistics,chi-square, independent samples t test, kappa and ANOVA (Post-hoc: Tukey) tests. Based on body mass index (BMI), $21.4 \%$ of the preschool children participating in the study were undernourished, $4.4 \%$ were overweight, $9.0 \%$ were obese while undernutrition was higher in girls (23.8\%) than in boys $(14.3 \%)(p>0.05)$. It was found that parents of the overweight and obese children were also overweight and obese $(p<0.001)$. Obese children $(n=45)$ based on BMI were evaluated by their mothers as normal $(66.7 \%)$ and undernourished $(2.2 \%)$, there was a weak correlation between the BMI of the child and the mother's assessment of the child's weight $(\boldsymbol{\kappa}=0.278$; $\mathrm{p}<0.001)$. Child's birth weight, parental approaches, the number of meals and skipping status of the child, fast-food consumption and advertisements affected the eating behaviours of the children $(p<0.05)$. According to these results, monitoring of BMI in schools and more frequent follow-up of children whose parents are overweight and obese by nurses at regular intervals are recommended for monitoring the growth of preschool children.
\end{abstract}

Keywords: Eating behavior in children, Nursing, Preschool children.

Bu çalıșma, 2019 yılında Nevsehir Hacı Bektas Veli Üniversitesi Fen Bilimleri Enstitüsü Hemşirelik Anabilim Dalında yüksek lisans tezi olarak kabul edilmiştir. Ayrlca bu çalışma, Nevşehir Hacı Bektaş Veli Üniversitesi Bilimsel Araştırma Projeleri YLTPF45 no' lu proje ile desteklenmiş olup 6. Uluslararası 17. Ulusal Hemşirelik Kongresi'nde (19-21 Aralık 2019, Ankara) sözel bildiri olarak sunulmuştur.

${ }^{1}$ MSc, Büşra Sema ALTUNSUYU, Hemşire, İnönü Üniversitesi Eğitim ve Araştırma Hastanesi Turgut Özal Tıp Merkezi Çocuk Kemik İliği Nakil Ünitesi, bsra_snmez@hotmail.com, ORCID: 0000-0002-8517-6421.

${ }^{2}$ Dr. Öğr. Üyesi, Zehra ÇALIŞKAN, Çocuk Sağlığı ve Hastalıkları Hemşireliği, Nevşehir Hacı Bektaş Veli Üniversitesi, Semra ve Vefa Küçük Sağlık Bilimleri Fakültesi, Hemşirelik Bölümü, zcaliskan26@gmail.com, ORCID: 0000-0002-4726-5052.

3 Prof. Dr., Semra KOCAÖZ, Kadın Sağlığı ve Hastalıkları Hemşireliği, Niğde Ömer Halisdemir Üniversitesi, Niğde Zübeyde Hanım Sağlık Yüksekokulu, Hemşirelik Bölümü, semrakocaoz@gmail.com, ORCID: 0000-0003-1698-6305. 


\section{GİRIȘ}

Yaşamin en temel gereksinimlerinden olan beslenme için besin almak, daha doğrusu yemek yeme ve yeme davranışı için iştah gerekmektedir. ${ }^{1}$ Çocukluk döneminde, iştahsızlık ve yeme sorunları nedeniyle sağlıklı çocuklarını doktora götüren ebeveynlerin oranının \%20-35 arasında olduğu bildirilmektedir. ${ }^{2}$ İştahsızlık sonucu yetersiz ve dengesiz alınan besinler çocuğun hızla gelişen fiziksel, zihinsel ve bilişsel işlevlerini, öğrenme yeteneklerini ve akademik başarılarını olumsuz yönde etkileyebilmektedir. ${ }^{3,}{ }^{4}$ Yetersiz beslenmenin uzun süreli olması, akranlarıyla kıyaslandığında çocuklarda yaşa göre kısa veya boya göre zayıf olma gibi gelişim geriliklerine neden olmaktadır. ${ }^{5}$ Birleşmiş Milletler Çocuklara Yardım Fonu (UNICEF), Dünya Sağlık Örgütü (WHO) ve Dünya Bankası (WBG) 2019 verilerine göre dünyada 5 yaş altı çocukların \%21,9'u (149 milyon) bodur (yaşa göre boyun -2 SD altında olması), $\% 7,3$ 'ü (49,5 milyon) ise zayıf-kavruktur (boya göre ağırlığın -2 SD altında olması). ${ }^{6}$ Ülkemizde beş yaş altı çocukların malnutrisyon oranlarına bakıldığında, Türkiye Beslenme ve Sağlık Araştırması (TBSA) 2010 verilerinde \%15,9; Türkiye Nüfus ve Sağlık Araştırması (TNSA) 2018 verilerine göre ise $\% 11,5$ 'dir. $^{7,8}$

Yeme davranışının bir uç noktası iştahsızlık iken diğer bir uç noktası da, belirli bir süre içinde çok miktarda yiyecek tüketilmesi olarak tanımlanan fazla iştahlılığın sebep olduğu aşırı yemedir. ${ }^{9}$ Kontrolsüz ve aşırı beslenme; çocukluk çağında başlayan obeziteye, insülin direncinin artmasına, Tip II diyabetin çok erken yaşlarda görülmesine, hipertansiyona, hiperlipidemi ile beraber metabolik sendroma ve kardiyovasküler olaylara zemin hazırlayabilmektedir. ${ }^{10}$ UNICEF, WHO ve World Bank Group 2019 y1lı verilerine göre dünyada 5 yaş altı çocukların \%5,9'unun (40,1 milyon) fazla kilolu olduğu tahmin edilmektedir. ${ }^{6}$ TBSA 2010 verilerine göre ise,
0-5 yaş arasındaki çocuklarda fazla kilolu olma s1klığ 1 \%17,9, obez olma s1klığ 1 $\% 8,5^{\prime}$ dir. $^{7}$ TNSA 2018 verilerinde 5 yaș altı çocukların \%8'i fazla kiloludur. ${ }^{8}$

Yeme davranışları sonucu meydana gelebilecek sorunlar nedeniyle özellikle kişiliğin büyük ölçüde şekillendiği okul öncesi dönemdeki çocukların kazandıkları beslenme alışkanlığı, sadece onların gelecekleri için değil aynı zamanda toplum sağlığı bakımından da önemlidir. ${ }^{11,} 12$ Okul öncesi dönemdeki çocuğun, yeterli beslenip beslenemediği, normalden sapmaların erken dönemde belirlenmesi ve gerekli önlemlerin alınması için en kolay ve en etkin yöntemin antropometrik ölçümler (boy, kilo, bel çevresi, BKİ, persentil değerleri, vb.) olduğu bilinmektedir. $^{13}$ Okul öncesi dönemdeki çocukların beslenme alışkanlıkları, yemek yeme davranışları ve bunları etkileyen faktörlerin tespit edilmesi çeşitli beslenme sorunlarının önlenmesinde etkili olacaktır. ${ }^{12}$

Ülkemizde okul öncesi çocukların hem yeme davranışları hem de antropometrik ölçümlerinin bir arada yapıldığı sınırlı sayıda çalışmaya rastlanılmıştır. ${ }^{14}$ TBSA 2010 verilerinde, İstatistiki Bölge Birimleri Sınıflandırmas1 (NUTS)'a göre Ortadoğu Anadolu Bölgesi'nde 5 yaş altı, düşük kilolu/çok zayıf $(\% 24,4)$ çocukların oranının yüksek; obez $(\% 12,7)$ çocukların oranının ise ilk beşinci sırada olduğu gösterilmiştir. ${ }^{7} \mathrm{O}$ nedenle bu bölgede okul öncesi dönemdeki çocukların yeme davranışları, antropometrik ölçümleri, kilo artışına ya da azalmasına neden olan durumların belirlenmesi önemlidir. Risk grubunda olan çocuklara yönelik koruyucu önlemlerin erken dönemde tespit edilmesi, yapilacak olan stratejik müdahalelerin planlanmasinda yararlı olacaktır. Bu araştırma düşük, orta ve yükssek sosyoekonomik düzey okullarında, 4-6 yaş grubundaki çocukların yemek yeme davranışlarını ve etkileyen faktörleri belirlemek amacıyla yapılmıştır. 


\section{MATERYAL VE METOT}

\section{Araştırmanın Türü, Evren ve Örneklem}

Tanımlayıcı tipte tasarlanan bu çalışmanın evrenini, İstatistiki Bölge Birimleri Sınıflandırması (NUTS)'a göre Ortadoğu Anadolu Bölgesi'nde bulunan bir ilin, 20172018 Eğitim-Öğretim yılında ilkokulların anasınıflarına (55 okul) devam eden 4-6 yaş grubu 1982 çocuk (Kız: 944, Erkek: 1038) ve onların ebeveyni oluşturmuştur.

Araştırmanın örneklem seçiminde, evreni bilinen örneklem genişliği formülü kullanılmıştır. ${ }^{15}$ Evreni belli olan örneklem genişliği formülünde $\% 95$ güven aralığında ve $\mathrm{p}=0,50$ olarak ele alındığında, alınması gereken katılımc1 sayısı 321 olarak hesaplanmıştır. Araştırma çalışmanın yapıldı ğ tarihlerde (Ekim 2017-Şubat 2018) dâhil edilme kriterlerini karşılayan 500 çocuk ve onların ebeveynleri ile tamamlanmıştır.

\section{Araştırmaya Dâhil Edilme Kriterleri}

Çalışmanın yapıldığı tarihlerde, okulların anasınıflarına kayıtlı 4-6 yaş grubu çocukların;

$$
\begin{aligned}
& \checkmark \text { Kronik hastalığı olmayan, } \\
& \checkmark \text { Egzersiz yapma gücünü } \\
& \text { engelleyebilen/yasaklayan fiziksel } \\
& \text { kısıtlamaları olmayan, } \\
& \checkmark \text { Velilerinden onam alınmış } \\
& \text { çocuklar ile, } \\
& \checkmark \text { İletişim problemi olmayan, } \\
& \text { çalısmaya katılmaya gönüllü olan } \\
& \text { tüm ebeveynler araştırma } \\
& \text { kapsamına alınmıştır. }
\end{aligned}
$$

Veri toplama sürecinde, velilerinden onam alınamayan ve formlarında eksiklikler olan ebeveyn ve çocuklar araştırma kapsamına dâhil edilmemiştir $(n=58)$.

Belirlenen örneklem sayısına ulaşmak için; belediye sınırları içerisinde bulunan 55 anaokulu İl Milli Eğitim Müdürlügü̈nce verilen bilgiler doğrultusunda sosyoekonomik düzeyi yüksek, orta, düşük mahallelerdeki okullar olarak ayrılmıştır. Bu üç düzeyde yer alan okullara sayı verip numaralandırılmış ve rastgele sayilar tablosu kullanılarak örnekleme seçilen okullar belirlenmiştir. Belirlenen okullarda örnekleme alınan öğrenci sayıları, sosyoekonomik düzeyi yüksek olan okullarda (3 okul) 163 çocuk, orta düzey okullarda (2 okul) 169 çocuk, düşük düzey okullarda ise (4 okul) 168 çocuk olmak üzere toplamda 500 çocuk ve onların ebeveynine ulaşılmıştır.

\section{Veri Toplama Araçları}

Araştırmada veriler; "Ebeveyn ve Çocuk Kişisel Veri Toplama Formu", "Çocuklarda Yeme Davranışı Anketi (ÇYDA)" kullanılarak toplanmıştır. Çocukların antropometrik ölçümlerinde elektronik baskül, boy ölçümünde çelik şerit metre, bel çevresi ölçümünde de esnemeyen mezura kullanılmıştır.

Ebeveyn ve çocuk kişisel veri toplama formu, araştırmaya katılan çocukların ve ebeveynlerin sosyo-demografik özelliklerini, çocukların beslenme alışkanlıklarını belirlemek amaciyla literatür taranarak araştırmacılar tarafından hazırlanmıştır. ${ }^{14,}$ 16, 17

Çocuklarda yeme davranışı anketi (ÇYDA), çocuklardaki obezite veya iştahsızlık eğilimini önceden belirlemeye olanak sağladığı düşünülen ÇYDA; ilk kez Wardle ve arkadaşlarınca 2001 yılında geliştirilmiştir. ${ }^{18}$ Türkçe uyarlaması, geçerlilik-güvenirliği Yılmaz ve arkadaşları tarafindan (2011) yapılmıştır (cronbach alpha 0,69). ${ }^{11}$ ÇYDA ebeveynlerin cevapladığı, 35 maddelik, 5'li likert tipi (1=Asla, 5=Her zaman) ve 8 alt boyutu bulunan bir ölçektir. ${ }^{11}$

Ölçeğin kesim noktası olmamakla birlikte grup karşılaştırmalarında her bir alt ölçeğin toplam puanları karşılaştırılabilmektedir. $\mathrm{Bu}$ çalışmada, "Çocuklarda Yeme Davranışı Anketi (ÇYDA)" ölçeğinin cronbach alpha değeri; 0, 702 olarak bulunmuştur.

Ölçeğin; Gıdaya erişim alt boyutlarını; Gıda Heveslisi (GH), Duygusal Aşırı Yeme (DAY), Gidadan Keyif Alma (GKA), Gıdadan uzaklaşma alt boyutlarını; Tokluk Heveslisi (TH), Yavaş Yeme (YY), Duygusal Az Yeme (DAZ), Yemek Seçiciliği (YS), 
Sivı alımı isteği alt boyutunu; İçme Tutkusu (IT) göstermektedir. ${ }^{11}$

\section{Verilerin toplanmast}

Okullardaki ilk ziyarette, veri toplama araçları, öğretmenler tarafindan ebeveynlere ulaştırılmıştır. Diğer ziyarette veri toplama araçlarını gönüllü olarak dolduran, onam formunu imzalayan ebeveynlerin çocuklarının boy, kilo ve bel çevreleri ölçülmüştür.

Antropometrik ölçümler, çocukların antropometrik ölçümleri (vücut ağırlığı, boy uzunluğu ve bel çevresi ölçümü) araştırmacılar tarafından yapılmıştır. Ebeveynlerin ise boy ve kilolarına ilişkin veriler, kendi beyanları doğrultusunda elde edilmiştir.

\section{Verilerin Değerlendirilmesi}

Araştırma verilerinin değerlendirilmesinde SPSS (Statistical Package for Social Sciences) 21.0 paket programı kullanılmıştır.

Verilerin değerlendirilmesi; tanımlayıcı istatistikler, çocukların yeme alışkanlıkları (ögün atlama ve fast-food tüketme) ile ölçek alt boyutlarının analiz edilmesinde Independent Samples $\mathrm{t}$ testi, çocukların doğum kilosu ağırlıkları, BKİ değerleri, yeme alışkanlıkları (öğün sayıları, reklamda gördüğü yiyeceği alma isteği), ebeveyn yaklaşımları (cezalandırma, ödüllendirme, yemek yerken uyarıda bulunma) ile ölçek alt boyutlarının analizinde Anova testi kullanılmıştır. Anova testi sonucunda istatistiksel olarak anlamlı fark olduğu tespit edilen değişkenler arasında farkın hangi gruptan kaynaklandığı Posthoc analizi ile incelenmiştir. Çocuğun BKİ'si ile annelerin çocuğun kilosunu değerlendirmesi arasındaki uyum için kappa testinden yararlanılmıştır. ${ }^{19}$ Anlamlılık düzeyi $\mathrm{p}<0,05$ olarak alınmıştır.
Öğrencilerin ağırlık ve boy ölçümleri sonrası, Beden Kütle İndeksi $\left(\mathrm{BKI} \dot{\mathrm{I}}=\mathrm{kg} / \mathrm{m}^{2}\right)$ hesaplanmıştır.

BKI'nin değerlendirilmesinde; Neyzi ve ark. (2008) tarafından geliştirilen büyüme eğrileri kullanılmıştır. Buna göre BKİ; 5-14,9 persentil zayif, 15-84,9 persentil normal kilolu, 85-94,9 persentil fazla kilolu, 95. persentil eğrisinin üzerinde olan çocuklar ise obez olarak sınıflandırılmıştır. ${ }^{20}$

Ebeveynlerin BKI'si beyan ettikleri boy ve kilo değerlerine göre hesaplanmıştır. (BKI $=\mathrm{kg} / \mathrm{m}^{2}$ ). WHO'nun obezite sınıflandırmasına göre BKI; $\leq 18,5$ zayıf, 18,6-24,9 normal, $\geq 25-29,9$ fazla kilolu, $\geq 30$ ise obez olarak nitelendirilmiștir. ${ }^{21,22}$

\section{Araştırmanın Etik Yönü}

Çalışma Helsinki Deklarasyonu Prensipleri' ne uygun olarak yürütülmüştür. Çalışma öncesi, Nevşehir Hacı Bektaş Veli Üniversitesi Girişimsel Olmayan Etik Kurulu'ndan (2017.08.07/24.02.2017) ve çalışmanın yapıldığı İl Milli Eğitim Müdürlüğü'nden (61316475-44-E. $14988579 / 26.09 .2017)$ yazılı onay alınmıştır.

Çalışma, Nevşehir Hacı Bektaş Veli Üniversitesi Bilimsel Araştırma Proje Birimi tarafindan (YLTPF45 no' lu proje ile) desteklenmiştir. Araştırmada, katılımcı ebeveynlere araştırmanın amacı açıklanarak gönüllü katılımları sağlanmış, sözlü ve yazılı izinleri alınmıştır. Çalışmada kullanılan, "Çocuklarda Yeme Davranışı Anketi" (ÇYDA) için de Yılmaz ve arkadaşlarından gerekli izin e-posta yoluyla alınmıştır.

\section{Araştırmanın Kısıtlılıkları}

Çalışmanın tek merkezde yürütülmesi, çocukların yemek yeme davranışları ve ebeveyn antropometrik ölçümlerinin ebeveyn tarafından bildirilmesi, araştırmanın sinırlılıkları arasında yer almaktadır.

\section{BULGULAR VE TARTIŞMA}

Bu çalışmada yaş ortalaması 5,2 yıl olan 4-6 yaş arası toplam 500 çocuk ve onların ebeveyni yer almıştır. Anneler büyük oranda $(\% 78,0)$ anketi dolduran ebeveyn olmuştur.
Çocukların \%45,4'ü kı, \%54,6's1 erkek, $\% 46,8$ 'inin ailenin ilk çocuğu olduğu, \%96,6'sının doğum kilosunun 2500-3500 gr ağırlığında olduğu ve doğum sonrasında anne 
sütü ile beslenmenin $\% 96$ olduğu belirlenmiştir.

Büyüme ve gelişmeyi göstermesinin yanı sıra çocukların durumunu da yansitan ölçümlerden biri BKİ'dir.

Çalışmaya katılan çocukların BKİ persentil değerine göre $\% 21,4$ 'ünün zayıf, \%4,4'ünün fazla kilolu, \%9'unun ise obez olduğu belirlenmiştir. Yapılan bu çalışmada, zayıflık $\% 23,8$ ile kızlarda, fazla kilolu ve obezite $\% 14,3$ ile erkeklerde fazla oranda saptanmıştır $(\mathrm{p}>0,05)$.

$\mathrm{Bu}$ araştırmanın bulgularıyla benzer şekilde, 3-6 yaş grubu çocukların antropometrik ölçümlerinin yapıldığ çalışmalarda da zayıf persentil değerinin kızlarda, fazla kiloluk ve obezite persentil değerinin erkeklerde daha fazla görüldüğü belirtilmektedir. ${ }^{7}, 14,23$
Cinsiyetler arasındaki bu farklılığın, kızların zayıf/zarif, erkeklerin ise gürbüz/kilolu görünmesinin toplumsal kabul görmesinden düşünülmektedir. ${ }^{2}$

TNSA 2018 verilerine göre ülkemizde yetersiz beslenme, sosyo-ekonomik statüsü nispeten daha düşük bir kesimin sorunu iken, fazla kiloluluk/şişmanlık ise sosyo-ekonomik statüsü yüksek kesimin bir sorunu olarak ön planda görünmektedir. ${ }^{8}$ Tablo 1 'de çalışmadaki okul bölgelerinin sosyoekonomik özellikleri ve çocukların BKİ durumlarına göre dağılımı görülmektedir. Yapılan bu çalışmada da literatürle uyumlu olarak, sosyoekonomik düzeyi yüksek olan bölgelerdeki okullarda obezite görülme oranının daha yüksek, sosyoekonomik düzeyi düşük olan bölgelerdeki okullarda ise zayıf persentili olan çocukların oranının yüksek olduğu saptanmıştır ( $<<0,001)$ (Tablo 1).

Tablo 1. Okul Bölgelerinin Sosyo-Ekonomik Özellikleri ve Çocukların BKİ Durumlarına Göre Dağılımı

\begin{tabular}{|c|c|c|c|c|c|c|c|c|c|c|c|}
\hline \multirow[b]{3}{*}{$\begin{array}{l}\text { Sosyo-ekonomik } \\
\text { düzey }\end{array}$} & \multicolumn{11}{|c|}{ Çocuk BKI } \\
\hline & \multicolumn{2}{|l|}{ Zayıf } & \multicolumn{2}{|l|}{ Normal } & \multicolumn{2}{|c|}{ Fazla kilolu } & \multicolumn{2}{|c|}{ Obez } & \multirow{2}{*}{$\begin{array}{c}\text { Toplam } \\
\mathrm{N}\end{array}$} & \multicolumn{2}{|r|}{ Test } \\
\hline & $\mathrm{n}$ & $\%$ & $\mathrm{n}$ & $\%$ & $\mathrm{n}$ & $\%$ & $\mathrm{n}$ & $\%$ & & $\%$ & \\
\hline Yüksek & 18 & 11,0 & 110 & 67,5 & 9 & 5,5 & 26 & 16,0 & 163 & 100,0 & \\
\hline Orta & 39 & 23,1 & 115 & 68,0 & 6 & 3,6 & 9 & 5,3 & 169 & 100,0 & $X^{2}=28,671$ \\
\hline Düşük & 50 & 29,8 & 101 & 60,1 & 7 & 4,2 & 10 & 6,0 & 168 & 100,0 & $p<0,001$ \\
\hline
\end{tabular}

Sosyoekonomik düzeyin düşük olduğu bölgelerde, yeterli ve dengeli beslenme ve sağlıklı yeme davranışı ile ilgili bilgi eksikliğinin olması, uygun besin bulabilme olanaklarının kısıtlı olması zayıflığın görülmesine neden olabilir. Sosyoekonomik düzeyin yüksek olduğu bölgelerde ise, çocukların içinde bulunduğu çevrenin sağlıksız beslenme alışkanlıklarına daha fazla yönlendirme yapması ve bu zararlı gidalara (abur-cubur, yüksek kalorili, yağlı gıdalar) imkânları sayesinde kolaylıkla ulaşmaları sonucu fazla kilo/obezitenin görüldüğü düşünülebilir.

Çocukların ailelerinin \%17'sinde obezite, \%40,4'ünde hipertansiyon, \%41,4'ünde diabetes mellitus olduğu belirlenmiştir. Ayrıca ebeveynlerin beyan ettiği boy ve kilo değerlerine göre BKİ'lerinin hesaplanması sonucu, annelerin \%36,2'sinin fazla kilolu, $\% 14,4$ 'ünün obez; babaların ise \%46,7'si fazla kilolu, \%15,0'ının obez olduğu saptanmıştır.

Ebeveynlerin genetik yapıs1, beslenme ve yaşam tarzları diğer alışkanlıklarda olduğu gibi çocukların beslenme alışkanlıklarını da etkilemektedir. ${ }^{25}$ Ebeveynlerinin ikisi de obez olan çocukların obez olma olasılığ 10 ila 12 kat daha fazladır. ${ }^{24}$ Yapılan çalışmalar, obez çocukların anne/babalarının da genel olarak şişman olduğunu göstermektedir. ${ }^{26-28}$ Tablo 2'de ebeveynlerin BKI'leri ve çocukların BKİ durumlarına göre dağılımına yer verilmiştir. $\mathrm{Bu}$ araştırma da literatür ile uyumlu olarak, BKI'ye göre fazla kilolu ve obez çocukların anne ve babalarının da diğerlerine göre daha yüksek oranda fazla kilolu veya obez olduğu 
bulunmuştur $(\mathrm{p}<0,001)$ (Tablo 2$)$. Bu sonuca göre hem genetik faktörlerin etkisi hem de anne babanın çocuklarını kendilerinin de içinde yer aldığ bırakmaları ve çocukların ebeveynlerini taklit ederek yeme davranışları geliştirmesi gibi sebeplerden, çocukların vücut ağırlıklarının olumsuz etkilendiği söylenebilir.

Tablo 2. Ebeveynlerin Beden Kütle İndeksleri ve Çocukların BKİ Durumlarına Göre Dağılımı

\begin{tabular}{|c|c|c|c|c|c|c|c|c|c|}
\hline \multirow{3}{*}{ Anne BKİ } & \multicolumn{9}{|c|}{ Çocuk BKİ } \\
\hline & \multicolumn{2}{|c|}{ Zayıf } & \multicolumn{2}{|l|}{ Normal } & \multicolumn{2}{|c|}{ Fazla kilolu } & \multicolumn{2}{|c|}{ Obez } & \multirow[t]{2}{*}{ Test } \\
\hline & $\mathrm{n}$ & $\%$ & $n$ & $\%$ & $\mathrm{n}$ & $\%$ & $\mathrm{n}$ & $\%$ & \\
\hline Zayıf & 2 & 1,9 & 4 & 1,2 & 1 & 4,5 & 0 & 0,0 & $X^{2}=27,661$ \\
\hline Normal & 62 & 57,9 & 159 & 48,8 & 7 & 31,8 & 12 & 26,7 & $\mathrm{p}=\mathbf{0 , 0 0 1}$ \\
\hline Fazla kilolu & 34 & 31,8 & 120 & 36,8 & 6 & 27,3 & 21 & 46,6 & \\
\hline Obez & 9 & 8,4 & 43 & 13,2 & 8 & 36,4 & 12 & 26,7 & \\
\hline Toplam & 107 & 100,0 & 326 & 100,0 & 22 & 100,0 & 45 & 100,0 & \\
\hline \multicolumn{10}{|c|}{ Baba BKI $(n=493) *$} \\
\hline Zayıf & 0 & 0,0 & 2 & 0,6 & 0 & 0,0 & 0 & 0,0 & $\mathrm{X}^{2}=33,290$ \\
\hline Normal & 46 & 43,8 & 126 & 39,1 & 6 & 28,6 & 9 & 20,0 & $\mathrm{p}=\mathbf{0 , 0 0 0}$ \\
\hline Fazla kilolu & 53 & 50,5 & 149 & 46,3 & 10 & 47,6 & 18 & 40,0 & \\
\hline Obez & 6 & 5,7 & 45 & 14,0 & 5 & 23,8 & 18 & 40,0 & \\
\hline Toplam & 105 & 100,0 & 322 & 100,0 & 21 & 100,0 & 45 & 100,0 & \\
\hline
\end{tabular}

Tablo 3'de çocukların BKİ ve annelerinin çocuğun kilosunu değerlendirme durumlarına yer verilmiştir. BKİ' ye göre obez olan çocukların (n:45) annelerinin; \%66,7'si (n:30) çocuklarının kilosunu normal, \%2,2'si (n:1) zayıf olarak değerlendirmiş olup, çocuğun BKİ'si ile annenin çocuğunun kilosunu değerlendirmesi arasında zayıf düzeyde $(\kappa=0,278 ; \mathrm{p}<0.001)$ uyum saptanmıştır.

Tablo 3. Çocukların Beden Kütle İndeksleri ve Annelerinin Çocuğun Kilosunu Değerlendirme Durumları

\begin{tabular}{|c|c|c|c|c|c|c|c|c|c|c|c|}
\hline \multirow{3}{*}{ Çocuk BKI } & \multicolumn{11}{|c|}{ Annenin çocuğun kilosunu değerlendirmesi } \\
\hline & \multicolumn{2}{|c|}{ Zayif } & \multicolumn{2}{|l|}{ Normal } & \multicolumn{2}{|c|}{ Fazla kilolu } & \multicolumn{2}{|c|}{ Obez } & \multirow{2}{*}{$\begin{array}{c}\text { Toplam } \\
\mathrm{N}\end{array}$} & \multicolumn{2}{|r|}{ Test } \\
\hline & $\mathrm{n}$ & $\%$ & $\mathrm{n}$ & $\%$ & $\mathrm{n}$ & $\%$ & $\mathrm{n}$ & $\%$ & & $\%$ & \\
\hline 5-14.9-Zayıf & 68 & 63,6 & 39 & 36,4 & 0 & 0,0 & 0 & 0,0 & 107 & 100,0 & \\
\hline 15-84.9-Normal & 75 & 23,0 & 250 & 76,7 & 0 & 0,0 & 1 & 0,3 & 326 & 100,0 & $\kappa=0,278$ \\
\hline 85-94.9 Fazla & 1 & 4,5 & 21 & 95,5 & 0 & 0,0 & 0 & 0,0 & 22 & 100,0 & $\mathrm{p}<0,001$ \\
\hline kilolu & 1 & 2,2 & 30 & 66,7 & 10 & 22,2 & 4 & 8,9 & 45 & 100,0 & \\
\hline 95 ve üzeri & & & & & & & & & & & \\
\hline Obez & & & & & & & & & & & \\
\hline
\end{tabular}

\section{\%: Yüzde, к: kappa \\ к:0.01-020: Önemsiz düzeyde uyum \\ к:0.21-040: Zaylf düzeyde uyum \\ к:0.41-060: Orta düzeyde uyum \\ $\kappa: 0.61-080:$ Iyi düzeyde uyum \\ к:0.81-1.00: Çok iyi düzeyde uyum ${ }^{19}$}

Yapılan birden fazla çalışmada, ebeveynlerin çocuklarının vücut ağırlığını nesnel olarak değerlendiremediği tespit edilmiştir. ${ }^{29-31}$ Aslan ve Şahin (2017)'in çalışmasında, ebeveynlerin \%32,9' unun çocuklarının kilosunun az olduğunu düşündükleri, \%92,4'ünün çocuğunun kilosunun fazla olduğunu düşündüklerini ifade ettiği görülürken, ebeveynlerin $\% 84,8$ 'inin çocuklarının ileride kilolu olmasına ilişkin endişe yaşamadığı belirlenmiştir. ${ }^{30}$ Yapılan bir diğer çalışmada $\mathrm{da}$, çocuğun kilosunun yanlış algılanmasının aslında ebeveynlerin tercihlerinin bir yansıması olduğu belirtilmiştir. ${ }^{31}$ Ebeveynlerin; "săgllklı çocuk=şişman çocuk" algısı ve çocuklarının fazla olan kilosunu "boyuna gider" şeklinde yorumlamaları, çocuklarının kilosunun olduğundan daha farklı görülmesine neden olabilir. Ebeveynlerin, çocuklarının vücut ağırlıklarını doğru değerlendirerek onları doğru beslenme alışkanlıklarına yönlendirmesinin, çocukluk çağında görülen obezitenin ve obeziteyle ilişkili hastalıkların önlenmesi, ayrıca aşırı kilolu veya obez 
çocukların sağlığının iyileştirilmesinde önemli bir adım olabileceği düşünülmektedir.

Çocuklarda Yeme Davranışı Anketi alt boyut puan ortalamalarına Tablo 4'de yer verilmiştir. Tabloya göre alt boyut puan ortalamaları GH, DAY, GKA için sırasıyla
$8,75 \pm 3,55,6,07 \pm 2,99,13,58 \pm 4,31 ;$ gidadan uzaklaşmayı gösteren alt boyutlar olan $\mathrm{TH}$, YY, DAZ ve YS için sirasiyla $22,55 \pm 5,53$, $11,32 \pm 3,98,11,64 \pm 4,30,7,32 \pm 3,03$ ve slv alımı isteğini gösteren IT için 7,61 $\pm 3,06$ olduğu belirlenmiştir.

Tablo 4. Çocuklarda Yeme Davranışı Anketi Alt Boyut Puan Ortalamaları

\begin{tabular}{lccr}
\hline & En düşük puan & En yüksek puan & Ort. \pm SD \\
\hline Gıda heveslisi (GH) & 5,0 & 24,0 & $8,75 \pm 3,55$ \\
Duygusal aşırı yeme (DAY) & 4,0 & 46,0 & $6,07 \pm 2,99$ \\
Gıdadan keyif alma (GKA) & 5,0 & 25,0 & $13,58 \pm 4,31$ \\
İçme tutkusu (IT) & 3,0 & 15,0 & $7,61 \pm 3,06$ \\
Tokluk heveslisi (TH) & 9,0 & 35,0 & $22,55 \pm 5,53$ \\
Yavaş yeme (YY) & 4,0 & 20,0 & $11,32 \pm 3,98$ \\
Duygusal az yeme (DAZ) & 4,0 & 54,0 & $11,64 \pm 4,30$ \\
Yemek seçiciliği (YS) & 3,0 & 28,0 & $7,32 \pm 3,03$ \\
\hline
\end{tabular}

Tablo 5'de çalışmaya katılan çocukların bazı değişkenleri ile ÇYDA alt boyut puan ortalamalarına yer verilmiştir. Bu çalışmada, BKI' ye göre obez olan çocuklarda ÇYDA gida heveslisi ve gidadan keyif alma puan ortalamalarının diğerlerine göre daha yüksek olduğu belirlenmiştir $(\mathrm{p}<0,001)$ (Tablo 5). Kanioğulları (2015)'nın araştırmasında da bu çalışmada olduğu gibi çocukların BKI' leri ile ÇYDA gıdadan keyif alma alt boyutunun pozitif yönde ilişkili olduğu belirtilmektedir. ${ }^{14}$ Literatürde iştahsızlığı ve gıdadan uzaklaşmayı gösteren ÇYDA alt boyutları (TH, YY, YS) ile iştahlılık ve gıdaya erişimi gösteren ÇYDA alt boyutlarının (GH, DAY, GKA) vücut ağırlığıyla ilişkili olduğu saptanmıştır. $^{32,33}$

Obezite için risk faktörlerinden biri de çocuğun doğum kilosudur. Çocukların farklı doğum ağırlığ düzeyleri ile obezite riski arasındaki ilişkinin 12 ülkede incelendiği bir araştırmada, doğum kilosu ile çocukluk çağ obezite oranları arasında pozitif ilişki olduğu belirlenmiştir. Doğum kilosu fazla olanlarda obezite riski belirlenmiş olmasına rağmen düşük doğum ağırlığının da obezite için bir risk faktörü olup olmadığı literatürde araştırılmaya ihtiyaç duyulan bir konu olarak geçmektedir. ${ }^{33}$ Yapılan bir çalıșmada düşük doğum ağırlığının, çocuğun özellikle 4-6 ay arası olmak üzere sonraki dönemde yeme davranışındaki zorlukla ilişkili olduğu saptanmıştır. ${ }^{35} \mathrm{Bu}$ çalışmada, çocuğun doğum kilosu arttıkça ÇYDA gıdadan keyif alma puan ortalamasının arttığı, çocukların doğum kilosu azaldıkça ise ÇYDA tokluk heveslisi ve yavaş yeme puan ortalamasının arttığ belirlenmiştir $(\mathrm{p}<0,05)$ (Tablo 5). Bu sonuca göre; çocukların doğum kilosunun, ilerleyen zamanlardaki antropometrik ölçümlerini etkileyebileceği ve gerekli tedbirlerin alınmasıyla çocukluk çağındaki obezitenin ve zayıflığının önlenmesinde katkısının olacağı düşünebilir.

Bu çalışmada okul öncesi çocukların yeme alışkanlıklarına da bakılmıştır. Okul öncesi dönem çocuklarına besinlerin, küçük mide kapasiteleri ve değişken iştahları olması nedeniyle, küçük porsiyonlar halinde günde 46 kez sunulması gerekmektedir. ${ }^{5} \mathrm{Bu}$ çalışmada çocukların öğün sayısı değerlendirildiğinde, \%23,4'ünün 1-2 öğün, \%74,2'sinin 3-4 öğün, \%2,4'ünün 5-6 öğün tükettiği belirlenmiştir. Öğün siklığının artması, çocukluk çağındaki fazla kiloluk/obezite için koruyucu bir faktör olabilir. ${ }^{36}$ Toschke ve ark. (2005) geniş örneklem üzerinde yaptıkları çalışmada, çocukların günde \%14,7'sinin üç, \%43,4'ünün dört, \%39'unun beş öğün besin tükettiği belirtilmiştir. ${ }^{36}$

Çalışmada, çocukların ögün sayısı arttıkça ÇYDA gıdaya erişim alt boyut (GH, DAY ve GKA) puan ortalamalarının arttığı ve gruplar arasındaki farkın istatistiksel olarak önemli 
olduğu saptanmıştır $(\mathrm{p}<0,05)$. Yapılan çoklu karşılaştırma testleri ile gıda heveslisi alt boyutu için tüm grupların, duygusal aşırı yeme alt boyutu için 5-6 öğün ve 1-2 öğün alan grupların, gidadan keyif alma alt boyutu için 1-2 öğün alan grubun anlamlılığ oluşturduğu bulunmuştur. Günde 1-2 öğün yiyen çocukların; ÇYDA tokluk heveslisi, yavaş yeme, duygusal az yeme puan ortalamalarının diğerlerine göre yüksek olduğu belirlenmiştir $(p<0,05)$ (Tablo 5).

Yine bu çalışmada, araştırmaya katılan çocukların yarısından fazlasının ögün atladığı $(\% 54,2)$, en fazla atlanan öğünün ise ikindi vakti ögünü $(\% 44,7)$ olduğu bulunmuştur. Ögün atlamayan çocukların ÇYDA gıdadan keyif alma puan ortalamasının yüksek ( $<<0,001$ ), öğün atlayan çocuklarda ise tokluk heveslisi, yavaş yeme ve duygusal az yeme puanlarının yüksek olduğu ve gruplar arası farkın istatistiksel olarak önemli olduğu bulunmuştur $(\mathrm{p}<0,05)$ (Tablo 5).

Bu çalışmada, fast-food tüketen çocuklarda ÇYDA içme tutkusu puan ortalamasının daha yüksek olduğu bulunmuştur $(\mathrm{p}=0,000)$ (Tablo 5). $\mathrm{Bu}$ duruma fast-food gidaların yanında genellikle yüksek kalorili ve şekerli içeceklerin verilmesinin etkisi olabileceği düşünülmektedir. Reklamlar yaş itibariyle okul öncesi çocukları etkileme-inandırma gücü sayesinde, onları sağlık açısından olumsuz yönde etkileyebilmektedir. ${ }^{37}$ Yapılan bu araştırmada reklamda gördüğünü almak isteyen okul

öncesi çocukların ÇYDA içme tutkusu, tokluk heveslisi, yemek seçiciliği ve duygusal aşırı yeme alt boyut puan ortalamalarının yüksek olduğu belirlenmiştir $(\mathrm{p}<0,05)$ (Tablo 5). Çocukların, ebeveynlere reklamlarda gördüğü yiyecek-içecekleri aldırmasıyla mutlu olup buna yanıt olarak aşırı yiyebileceği; reklam ürünlerinde animasyon karakterlerinin kullanılmasıyla çocukların bu ürünlere karşı bağ kurabileceğgi belirtilmektedir. ${ }^{16}$ Çocuk bu bağ sayesinde, sadece reklamda gördüğü gıda ürünlerini yemek-içmek isteyip diğer yiyecekiçeceklere karşı tok ve seçici olabilir. Yüksek kalorili içeceklerin dış ambalajının çizgi film karakterleri ile yapılması, çocukları sıvı alım isteğine yönlendirmede, yine reklamların etkili olabileceğini düşündürebilir.

Okul öncesi dönem çocuklarının yeme davranışını etkileyen faktörlerden biri de ebeveynlerin yaklaşımları olabilir. $\mathrm{Bu}$ araştırmada çocuklara yemesi için uyarıda bulunan ebeveynlerin oranlarının yüksek olduğu $(\% 53,2)$, ebeveynlerin yarısından fazlasinın $(\% 67,2)$ yemede ödüllendirme yöntemini kullandığ1 (evet:\%22,6, bazen:\%42,6), cezalandırma uygulamalarının ise ebeveynler tarafindan \%29,2 oranla (evet:\%4, bazen:\%25,2) tercih edildiği belirlenmiştir. Kobak ve Pek'in yaptığ 1 (2015) çalışma sonucunda; anne-babaların çocukları yemek yemediği zaman $\% 18,5^{\prime} i$ ödül yöntemini, \%3,1 ise ceza yöntemini kullandıkları belirlenmiştir. ${ }^{17}$ Özdoğan ve ark. (2018) yaptıkları çalışmada yeme baskısı uygulayan ebeveynlerin çocuklarında ÇYDA yemek seçiciliği, tokluk heveslisi ve yavaş yeme alt boyutları puan ortalamaları arasında pozitif yönlü korelasyon belirtilmiştir. ${ }^{38}$

Tablo 5. Bazı Değişkenler ile Çocuklarda Yeme Davranışı Anketi Alt Boyut Puan Ortalamaları

\begin{tabular}{|c|c|c|c|c|c|c|c|c|}
\hline \multirow{2}{*}{ Değişkenler } & \multicolumn{8}{|c|}{ Çocuklarda Yeme Davranışı Anketi } \\
\hline & $\mathrm{GH}$ & DAY & GKA & IT & $\mathrm{TH}$ & YY & DAZ & YS \\
\hline \multicolumn{9}{|l|}{$\begin{array}{l}\text { Doğum ă̆ırlı̆̆ı } \\
(g r)\end{array}$} \\
\hline$<2500 \mathrm{gr}$ & $8,74 \pm 3,77$ & $6,00 \pm 2,12$ & $12,46 \pm 4,88$ & $7,69 \pm 3,31$ & $23,55 \pm 5,87$ & $12,47 \pm 4,03$ & $12,38 \pm 5,70$ & $6,77 \pm 2,55$ \\
\hline $2500-3500 \mathrm{gr}$ & $8,62 \pm 3,35$ & $6,02 \pm 3,20$ & $13,58 \pm 4,18$ & $7,62 \pm 2,99$ & $22,68 \pm 5,45$ & $11,44 \pm 3,98$ & $11,64 \pm 4,15$ & $7,33 \pm 2,89$ \\
\hline$>3500 \mathrm{gr}$ & $9,28 \pm 4,07$ & $6,32 \pm 2,63$ & $14,35 \pm 4,27$ & $7,47 \pm 3,20$ & $21,32 \pm 5,45$ & $10,00 \pm 3,63$ & $11,10 \pm 3,69$ & $7,69 \pm 3,74$ \\
\hline Test** & 1,227 & 0,379 & 3,611 & 0,123 & 3,358 & 7,922 & 1,632 & 1,702 \\
\hline $\mathrm{p}$ & 0,294 & 0,685 & $\mathbf{0 , 0 2 8}$ & 0,885 & 0,036 & $\mathbf{0 , 0 0 0}$ & 0,197 & 0,183 \\
\hline \multicolumn{9}{|l|}{ Çocuk BKI } \\
\hline Zayıf & $8,45 \pm 3,32$ & $6,20 \pm 2,55$ & $11,98 \pm 4,00$ & $8,05 \pm 3,17$ & $23,70 \pm 5,22$ & $12,90 \pm 3,75$ & $12,35 \pm 6,10$ & $7,12 \pm 2,57$ \\
\hline Normal & $8,39 \pm 2,91$ & $5,87 \pm 3,13$ & $13,65 \pm 3,93$ & $7,49 \pm 3,09$ & $22,27 \pm 5,59$ & $11,18 \pm 3,91$ & $11,54 \pm 3,64$ & $7,30 \pm 3,07$ \\
\hline Fazla kilolu & $10,13 \pm 4,52$ & $7,18 \pm 3,24$ & $14,90 \pm 5,22$ & $7,59 \pm 2,97$ & $23,45 \pm 5,57$ & $10,31 \pm 4,46$ & $11,86 \pm 3,46$ & $7,59 \pm 2,98$ \\
\hline Obez & $11,37 \pm 5,86$ & $6,68 \pm 2,61$ & $16,15 \pm 5,60$ & $7,42 \pm 2,63$ & $21,42 \pm 5,45$ & $9,02 \pm 3,40$ & $30,53 \pm 3,76$ & $7,84 \pm 3,71$ \\
\hline Test $* *$ & 11,322 & 2,209 & 11,670 & 0,973 & 2,663 & 11,961 & 2,057 & 0,662 \\
\hline $\mathrm{p}$ & $<0,001$ & 0,086 & $<0,001$ & 0,405 & 0,047 & $<0,001$ & 0,105 & 0,576 \\
\hline
\end{tabular}




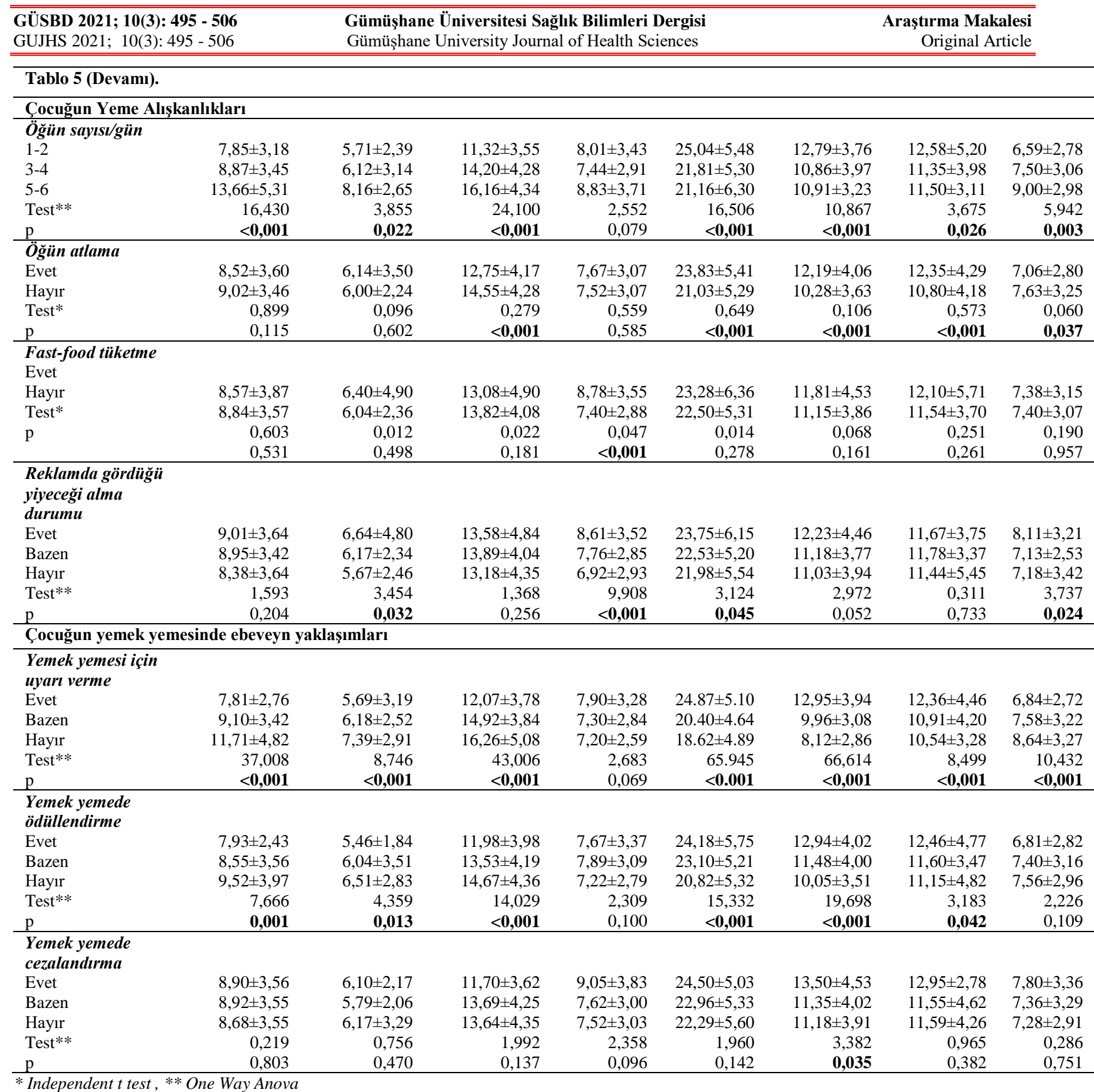

Tokyo'da anaokullarında çocuğu bulunan annelerin yer aldığ 1 bir çalışmada, besin seçiciliği ve besinden daha az keyif alma annenin yeme baskısı ile ilișkili değerlendirilmiştir. ${ }^{39}$ Yapılan bu araştırmada; ebeveynlerin yemek yemede ödüllendirme uygulamasını kullandığı çocuklarda, ÇYDA gıdadan uzaklaşma alt boyutları (TH, DAZ ve YY) puan ortalamalarının daha yüksek olduğu belirlenmiştir $(\mathrm{p}<0,05)$ (Tablo 5). Çalışmada, ebeveynlerin yemede cezalandırma uygulamasını kullandığı çocuklarda ise ÇYDA yavaş yeme alt boyut puan ortalamasının daha yüksek $(\mathrm{p}<0,05)$ olduğu bulunmuştur (Tablo 5). Ebeveynlerin, çocuklarının besleyici gıdaları daha fazla almalarını sağlamak için tatlı besinleri ödül olarak kullandıkları ve bu kullanılan yöntemin çocuklar tarafindan tatlı besinlerin tercih edilmesine yol açtığı belirtilmektedir. ${ }^{40}$

Çocukların sağlıklı ve istenilen besinleri tükettiğinde ebeveynlerin çocuklarını gıda ürünleriyle değil, özenle seçilmiş ve güzel sözcüklerle ödüllendirmeleri tavsiye edilebilir. 


\section{SONUÇ VE ÖNERILER}

Düşük, orta ve yüksek sosyoekonomik düzeyde 4-6 yaş grubu çocukların yemek yeme davranışları ve etkileyen faktörlerin belirlenmesi amacıyla yapılan bu çalışmada;

Okul öncesi çocukların antropometrik özellikleri ile yemek yeme davranışları arasında ilişki olduğu, literatürle benzer olarak çocukların yemek yeme davranışlarının (doğum kilosu, ögün sayısı, öğün atlama, fastfood tüketimi, reklamlar, ebeveyn yaklaşımları vb.) çeşitli faktörlerden etkilendiği belirlenmiştir.

$\mathrm{Bu}$ araştırmanın bulgularına dayanarak;

- Okul sağlığı hizmetlerini yürüten ekip içerisinde yer alan okul sağlığı hemşirelerinin, çocukların sağlığının korunması ve geliştirilmesine yönelik olarak; BKİ' ye göre, zayif, fazla kilolu ve obezite riski bulunan çocukların belirlenmesinde anahtar rolleri bulunmaktadır. Büyüme ve gelişmenin izlenmesi, normalden sapmaların erken dönemde fark edilmesi ve önlem alınması için okullarda BKİ izleminin yapılması,

-Çocukların beslenme ve yemek yeme davranışlarına ilişkin gözlemlerin yapılıp değerlendirilmesi,

- Okul sağlığı hemşirelerinin, ebeveynleri obez ya da fazla kilolu olan çocukların izlem sıklığını arttırması, aile ve çocuklara sağlıklı beslenme ile doğru beslenme alışkanlıklarının kazandırılması konusunda eğitim ve danışmanlık vermesi,

-Okul öncesi dönem çocuklarının genel özellikleri, beslenme özellikleri ve yeme davranışları ailelere anlatılarak toplumun bilgilendirilmesi/farkındalıklarının artırılmas1,

-Ebeveynlere, çocuklarının kilo durumlarını doğru algılamasında farkındalıklarının artırılmasına yönelik eğitim ve danışmanlık verilmesi,

- Ebeveyn tutumları, ailenin örnek alındığı dönem olan okul öncesi dönemdeki çocukların yeme davranışlarında oldukça etkilidir. İstenilen ve sağlıklı olduğu düşünülen gıdaların tüketildiğinde șekerli gıdaların ödül olarak sunulmasıyla aslında çocuklarının obez olmalarına zemin hazırladıkları konusunda ailelerin bilinçlendirilmesi,

-Çocuğun aile tarafindan istenmeyen yeme davranışının cezalandırma yöntemiyle bırakmasını sağlamak yerine, yeterli ve dengeli beslenmenin önemini çocuklarına anlatarak doğru yeme alışkanlıkları kazandırmaları,

-Ayrıca okul öncesi çocukların yemek yeme davranışını etkileyen faktörleri belirlemede çok merkezli geniş örneklem düzeyinde çalışmaların yapılması önerilmektedir.
1. Merdol, K.T. (2017). "İstahsız Çocuk Yönetimi Diyetisyenlere Düşen Görevler”. Beslenme ve Diyet Dergisi, 45 (3), 199-203.

2. Wright, C. and Birks, E. (2000). "Risk Factors For Failure To Thrive: A Population-Based Survey". Child Care Health Development, 26 (1), 5-16. https://doi.org/10.10 $46 / j .1365-2214.2000 .00135 . x$

3. World Health Organization. (2019). "Children: reducing mortality". https://www.who.int/en/news-room/factsheets/detail/children-reducing-mortality (Erişim Tarihi: 08.05.2019)

4. T.C. Sağlık Bakanlığı Sağlık Eğitimi Genel Müdürlüğü. (2008). Eğitimciler İçin Eğitim Rehberi Beslenme Modülleri. Ankara: İlkay Ofset Matbaacılık.

5. Anne Çocuk Eğitim Vakfi. (AÇEV). (2017). "Türkiye'de 0-6 Yaş Cocuğun Durumu'. https://www.acev.org/wp-
content/uploads/2018/01/Tu\%CC\%88rkiyede-0-6-Yas\% CC\%A7-C\%CC\%A7ocug\%CC\%86un-Durumu.24.10. 17.pdf (Erişim Tarihi: 12.06.2019).

6. UNICEF/ WHO/World Bank Group Joint Malnutrition Estimates. (2019). Key findings of the 2019 edition. "Levels and trends in child malnutrition". https://www.who.int/nutgrowthdb/jme-2019-keyfindings.pdf?ua=1 (Erişim tarihi: 18.05.2019).

7. T.C. Sağlık Bakanlığı Sağlık Araştırmaları Genel Müdürlüğü, Hacettepe Üniversitesi Sağlık Bilimleri Fakültesi Beslenme ve Diyetetik Bölümü, Ankara Numune Eğitim ve Araștırma Hastanesi. (2014). "Türkiye Beslenme ve Sağlı Araștırması (TBSA) (2010): Beslenme Durumu ve Alışkanlıklarının Değerlendirilmesi Sonuç Raporu”, Ankara, 2014.

8. Hacettepe Üniversitesi Nüfus Etütleri Enstitüsü. (2019). "2018 Türkiye Nüfus ve Sağlık Araştırması”. Hacettepe 
Üniversitesi Nüfus Etütleri Enstitüsü, T.C. Cumhurbaşkanlığı Strateji ve Bütçe Başkanlığı ve TÜBİTAK, Ankara, Türkiye.

9. Baysal, A. (2002). "Genel Beslenme”, Ankara: Hatipoğlu Yayınları.

10. Baughcum, A, Powers, S, Johnson, S.B, Chamberlin, L.A, Deeks, C.M, Jain, A, and Whitaker, R.C. (2001) "Maternal Feeding Practices and Beliefs and Thei Relationships to Overweight in Early Childhood". Development Behaviour Pediatr, 22 (6), 391-408 https://doi.org/ 10.1097 / 00004703-200112000-00007.

11. Yılmaz, R. and Erkorkmaz, Ü. (2011). "Adaptation Study of the Turkish Children's Eating Behavior Questionnaire'. Anatolian Journal of Psychiatry. 12, 287. 94.

12. Aydın, G, Akay, D. ve İbiş E. (2017). "3-7 Yaş Çocuğa Sahip Annelerin Beslenmeyle İlgili Davranıslarının İncelenmesi”. Trakya Üniversitesi Eğitim Bilimleri Dergisi, 7 (2), 683-700. https://doi.org/10.24315/trkefd. 307013

13. Yardımcı, H, Örmeci, Ö.F, Özçelik, Ö.A, Sürücüoğlu, S.M. ve Özdoğan Y. (2015). "Nutrition Education In Preschool Children". Uluslararası Eğitim Bilimleri Dergisi / The Journal of International Education Science, 2 (5), 449-457.

14. Kanioğulları, O.A. (2015). "Lefkoşa'da Kreş ve Anaokuluna Devam Eden Cocukların Beslenme Davranışlarına ve Vücut Ağırlığına Annenin Cocuk Besleme Tutum ve Davranışlarının Etkisi”. Lisansüstï Eğitim, Öğretim ve Araștırma Enstitüsü, Doğu Akdeniz Üniversitesi Beslenme ve Diyetetik Bölümü, Yüksek Lisans Tezi, Kıbris.

15. Esin, N. (2014). Örnekleme. Hemşirelikte Araştırma, Edt: Semra Erdoğan, syf: 167-192, İstanbul: Nobel Tip Kitapevi.

16. Yıldı, E.Ö. ve Deneçli, C. (2013). "Reklamda Animasyon Karakter Kullanımının Çocukların Beslenme Alıșkanlıkları Üzerindeki Etkileri’. İletișim Kuram ve Araştırma Dergisi, 36, 242-53

17. Kobak, C. ve Pek, H. (2015). "Okul Öncesi Dönemde (36 Yaş) Ana Çocuk Sağlığı ve Anaokulundaki Çocukların Beslenme Özelliklerinin Karsılaștırılması". Hacettepe Üniversitesi Eğitim Fakültesi Dergisi, 30 (2), 42-55.

18. Wardle, J, Guthrie, C.A, Sanderson, S. and Rapoport, 1. (2001). "Development of the Children's Eating Behaviour Questionnaire". Journal of Child Psychology Psychiatry, 42 (7), 963-970. https://doi.org/ 10.1111/1469-7610.007 92.

19. Kılıç, S. (2015). "Kappa Testi”. Journal of Mood Disorders Volume,5 (3), 142-144. https://doi.org/ 10.5455/jmood.20150920115439

20. Neyzi, O, Günöz, H, Furman, A, Bundak, R, Gökçay, G, Darendeliler, F. ve Baş F. (2008). "Türk Çocuklarında Vücut Ağırlı̆̆ı, Boy Uzunluğu, Bas Cevresi ve Vücut Kitle İndeksi Referans Değerleri’’. Çocuk Sağlığı ve Hastalıkları Dergisi, 51 (1), 1-14.

21. World Health Organization. (2012). "Population-Based Approaches to Childhood Obesity Prevention", WHO Library Cataloguing, s:13-14.

22. TEMD Obezite, Lipid Metabolizması, Hipertansiyon Çalışma Grubu. (2017). "Obezite Tanı ve Tedavi Kılavuzu'”. Türkiye Endokrinoloji ve Metabolizma Derneği, s:11-19.
23. Ji, M, Tang, A, Zhang, Y, Zou, J, Zhou, G, Deng, J, Yang, L, Li, M, Chen, J, Qin, H. and Lin, Q. (2018). "The Relationship between Obesity, Sleep and Physical Activity in Chinese Preschool Children". International Journal of Environmental Research and Public Health, 15 (3), 527. https://doi.org/ 10.3390/ijerph15030527.

24. Kerkez, İ.F, Tutal, V. ve Akçınar, F. (2013). "Okul Önces Dönemde Beden İmaj1 Algısı ve Beden Memnuniyetsizliği”. Hacettepe Journal of Sport Sciences, 24 (3), 234-244

25. Mallan, K.M, Daniels, L.A, Nothard, M, Nicholson, J.M, Wilson, A, Cameron, CM, Scuffham, PA, and Thorpe, K (2014). "Dads at the Dinner Table. A Cross-Sectional Study of Australian Father's Child Feding Perceptions and Practices". Appetite, 73, 40-44. https://doi.org/1016 / j.appet.2013.10.006.

26. Whitaker, K.L, Jarvis, M.J, Beeken, R.J, Boniface, D. and Wardle, J. (2010). "Comparing Maternal and Paternal İntergenerational Transmission of Obesity Risk in a Large Population-Based Sample". The American Journal of Clinical Nutrition, $91 \quad$ (6), 1560-1567. https://doi.org/10.3945/ajcn.2009.28838.

27. Çalışır, H, and Karaçam, Z. (2011). "The Prevalence of Overweight and Obesity in Primary Schoolchildren and Itts Correlation with Sociodemographic Factors in Aydın, Turkey". Internatiol Journal of Nursing Practice, 17, 16673. https://doi.org/10.1111/j.1440-172X.2011.01922.x

28. Koç, N, Bülbül, S.F, Akıncı, N, Yıldız, C.K. ve Bölükbaş, S. (2018). "Obez Cocukların Anne/Babalarının Beden Kütle İndeksleri Beden Algılarını Etkiler mi?'”. Ankara Sağlık Bilimleri Dergisi, 7 (2), 11-20.

29. Peker, E, Topaloğlu, N, Şahin, E.M, et al. (2014). "The Comparison of Parent's Perception on Weight, Appearance and Appetite of Their Children with Objective Criteria". Turkiye Aile Hekimligi Dergisi, 18 (3), 142-148.https://doi.org/10.15511/tahd.14.03142

30. Aslan, F. ve Sahin, E.N. (2017). "Ebeveynlerin Çocuklarının Beslenme ve Kilo Durumlarına İlişkin Görüslerinin Belirlenmesi’’ Gümüshane Üniversitesi Sağlık Bilimleri Dergisi, 6 (1), 20-28.

31. Pasch, A.L, Penilla, C, Tschann, M.J, Martinez, M.S, Deardorff, J, Groat, L.C, Gregorich, E.S, Flores, E, Butte, F.N. and Greenspan, C.L. (2016). "Preferred Child Body Size and Parental Underestimation of Child Weight in Mexican American Families". Matern Child Health Journal, 20 (9), 1842-1848. https://doi.org/10.1016/ j.appet.2017.06.016.

32. Özer, S, Bozkurt, H, Sönmezgöz, E, Bilge, S, Y1lmaz, R. ve Demir, O. (2014). "Obezite Tanılı Cocuklarda Yeme Davranısıının Değerlendirilmesi”. Cocuk Dergisi, 14 (2), 66-71. https://doi.org/10.5222/j.child.2014.066

33. Domoff, S.E, Miller, A.L, Kaciroti, N. and Lumeng, J.C (2015). "Validation of the Children's Eating Behaviour Questionnaire in A Low-Income Preschool-Aged Sample in The United States". Appetite, 95, 415-420. https://doi.org/10.1016/j.appet.2015.08.002

34. Qiao, Y.M.J, Wang, Y, Li, W, Katzmarzyk, P, Chaput, J.P, Fogelholm, M, Johnson, DW, Kuriyan, R, Kurpad, A Lambert, V.E, Maher, C, Maia, J, Matsudo, V, Olds, T, Onywera, V, Sarmiento, L.O, Standage, M, Tremblay, S.M, Tudor-Locke, C, Church, S.T, Zhao, P. and Hu, G. (2015). "Birth Weight and Childhood Obesity: A 12Country Study". International Journal Obesity Supplements, 5 (2), 74-79. https://doi.org/10.3390/nu110 40848 . 
35. Oliveria, A, Lauzon-Guillain, B, Jones, L, Emmett, $\mathrm{P}$ Moreira, P, Ramos, E, Charles, A.M. and Lopes, C. (2015). "Birth Weight and Eating Behaviors of Young Children". The Journal of Pediatrics, 166: 59-55. https://doi.org/10.1016/j.jpeds.2014.09.031.

36. Toschke, M.A, Küchenhoff, H, Koletzko, B. and Kries, R. (2005). "Meal Frequency and Childhood Obesity". Obesity Research, 13 (11), 1932-1938. https://doi.org/10.1038/oby.2005.238.

37. Asena, B.M. (2009). "Gıda Reklamlarının Okul Öncesi Cocuklar Üzerindeki Etkilerinin Anneler Tarafindan Değerlendirilmesi”. T.C. Bahçeşehir Üniversitesi Sosyal Bilimler Enstitüsü, Yüksek Lisans Tezi, İstanbul.
38. Özdoğan, Y, Balaban, S. ve Uçar, A. (2018). “Annelerin Çocuk Besleme Uygulamaları ve Çocukların Yemek Yeme Davranışları". Nevșehir Bilim ve Teknoloji Dergisi, 7 (1), 1-13. https://doi.org/10.17100/nevbiltek.326672

39. Ainuki, T. and Akamatsu, R. (2011). "Associations Between Children's Appetite Patterns and Maternal Feeding Practices". Food and Nutrition Sciences, 2, 228-234. https://doi.org/10.4236/fns.2011.23032.

40. Yiğit, R. (2011). "Cocukluk Dönemi Obezitesinin Yönetiminde Hemşirenin Rolü”. Hemşirelikte Araştırma Geliştirme Dergisi, 1, 71-80. 